\title{
Solid-Phase Speciation of Copper in Mine Wastes
}

\author{
Jaebong Jeong \\ Deparment of Ciwil and Emirommental Engineering \& Lake Superior Ecoswstem Research Center. \\ Michigan Technological Lniwersitw, 1400 Townsend Drive. Houghton, M 19931. LSt \\ Received October 15, 2002
}

\begin{abstract}
Ecosystems in the Keweenaw Peninsula region of Lake Superior. USA. were disturbed by over 500 million tons of copper-rich mine tailings during the period 1850-1968. Metals leaching from these mine residues have had dramatic effects on the ecosystems. Vast acreages of exposed tailings that are over 100 years old remain unvegetated because of the combination of metal toxicity. absence of nutrients. and temperature and water stress. Therefore. it is important to characterize and fractionate solid copper phases for assessing labile forms of copper in soils and sediments contaminated by the mining wastes. X-ray diffraction analyses indicate that calcite. quartz. hematite. orthoclase and sanidine minerals are present as major minerals. whereas cuprite. tenorite. malachite. and chalcopy rite might be present as copper minerals in the mining wastes. Sequential extraction technique revealed that carbonate and oxide fractions were the largest pools of copper (ca. 50-80\%) in lakeshore and wetland stamp sands whereas the organic matter fraction was the largest reservoir $(\mathrm{ca}$. 32\%) in the lake sediments. The concentrations of iron and copper were inversely correlated in the oxide fraction suggesting that copper may occur as a surface coating on iron oxides. As particle size and water contents decrease. the percent of the copper bound to the labile carbonate fraction increases.
\end{abstract}

Key Words : Lake Superior. Copper. Solid-phase speciation, Mine tailings

\section{Introduction}

Copper is an important metal having been used to make tools. weapons utensils and ornaments for several thousand years in human civilization. ${ }^{1-3}$ Therefore. the areas surrounding processing and mining facilities have been exposed to high levels of copper because of transport and cycling of copper. Many research groups have investigated the impacts of mining activities on surface and ground waters. ${ }^{+6}$ The surface water and poor water in deep "pit lakes". formed after cessation of mining activities. have been found to have high concentrations of metals and to lack oxygen. ${ }^{4}$ Mining effluents caused elevated concentrations of metals (Cu. Fe. $\mathrm{Mg}$. and $\mathrm{Ca}$ ) in sediments in the catchument of Coniston Water in the English Lake District due to erosion from a local mining operation." Trace metal concentrations in the surface and pore waters of the Clark Fork River basin have diminished aquatic life in the regions stream because of by products of copper mining in the upper stream. ${ }^{6}$

The Keweenaw Peninsula became one of the largest mining regions of North America at the turn of the century due to deposits of native copper. Copper was extracted by steam-driven stamp mills with a great volume of low-grade ores. resulting in huge amounts of crushed waste ore. Copper mining had been continuous in this area for 150 years. ${ }^{7-9}$ Although mines produced mainly copper the mining wastes/ tailings called stamp sands were produced as co-products. ${ }^{7}$ Approximately one half giga tons of copper mine tailings was dumped along rivers. waterways. lakes. and Lake Superior shores on the Keweenaw Peninsula region of Lake

"Phone: +1-906-482-2524; Fax: +1-906-487-2943; E-mail: jieong ầintu.edu
Superior. The major copper tailing dumping sites are Torch Lake. Boston wetland. Freda-Redrige. and Gay. ${ }^{?}$

Due to the dumping of copper-rich mine waste on the region. high concentrations of copper and other metals have been investigated in sediments since the 1970 's ${ }^{10.11}$ Several regulatory actions have been taken by Michigan's Water Resources Commission (MWRC), the Michigan Department of Natural Resources (MDNR), and the United States Environmental Protection Agency (U.S. EPA) in this Great Lakes Area of Concern (AOC) since the 1970's. ${ }^{12}$ Torch Lake and tributary areas were added to the U.S. EPA National Priorities List in 1984. The EPA has subdivided the area into three operable units (OU). Operable Unit I (OU I) and II (OU II) include the western shore of Torch Lake and the area of potential contamination in and around Torch Lake. respectively (Figure 1). Operable Unit III (OU III) includes other tailings sources in the mid-Keweenaw Peninsula along with the Keweenaw waterway.

Copper is one of the trace elements essential to the health of plants and animals. ${ }^{13.14}$ However. elevated concentrations of copper are toxic to aquatic organisms such as algae. ${ }^{15-18}$ benthic invertebrates. ${ }^{3.19}$ and juvenile fish. ${ }^{2.2021}$ In the $1970 \mathrm{~s}$. it was observed that many saugers had external growths on their bodies or fatty growths within the body cavity." It was also found that changes in benthic macroinvertebrate populations were related to concentrations of copper released from copper-rich sediments in the surface water in the Keweenaw waterway. ${ }^{16.19}$ Concentrations of copper in the lake and pore waters were measured and analyzed with respect to toxicity of copper: both found that levels of copper in surface (3-60 ppb) and pore waters $(120-1300 \mathrm{ppb})$ were higher than the levels considered as toxic $(30-600 \mathrm{ppb}){ }^{12.22}$ 


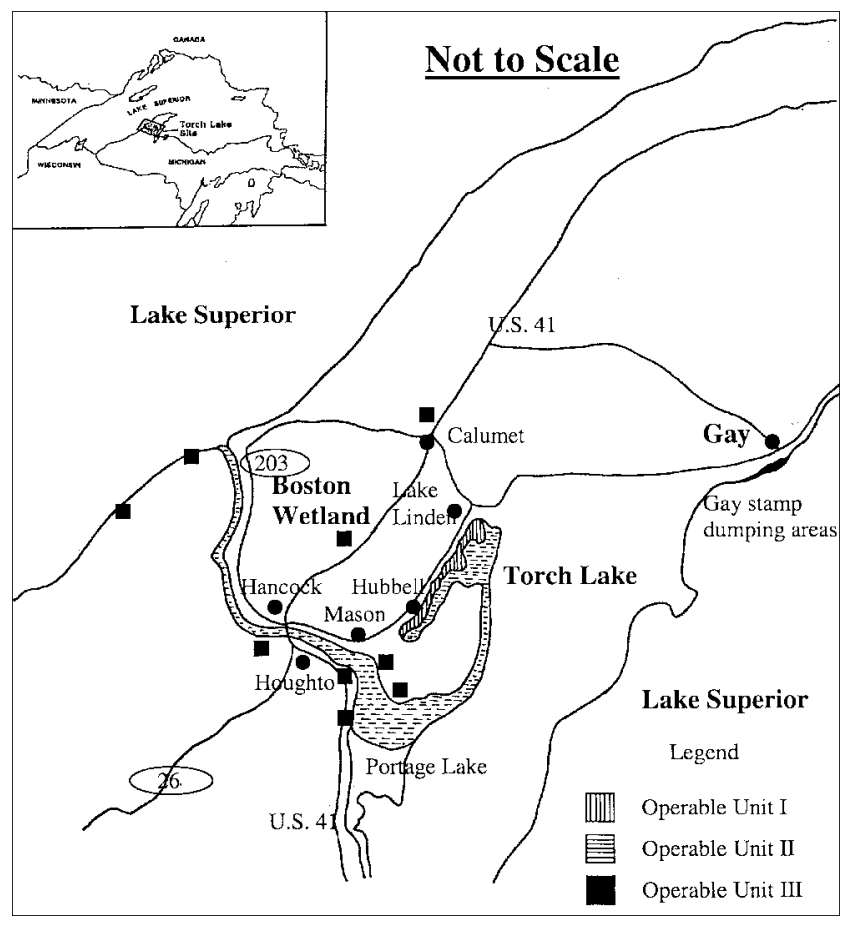

Figure 1. Torch Lake Superfind site and Gay, MI (modified from U.S. EPA 1989).

The threat posed by metals to the environment is thought to be dependent on their mobility and bioavailability. Therefore. it is necessary to understand and fractionate the different physicochemical forms of metals in soils and sediments. Metals are found in several different forms like sulfides. sulfates. carbonates. silicates. and oxides and also occur as

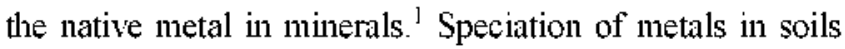
and sediments has been extensively studied using selective chemical extraction methods and sequential extraction techniques.3-26 Sequential extraction tecluniques are employed widely to obtain information on metal speciation in soils and sediments. This method is based on a combination of specific extractions. Although sequential extractions take more time to carry out. they furnish detailed information about the origin. mode of occurrence biological and physiochemical availability: mobilization. and transport of trace metals. ${ }^{27-29}$ An analytical procedure involving sequential chemical extractions was developed for the partitioning of particulate trace metals into five fractions: exchangeable. bound to carbonate. bound to oxide bound to organic matter. and residual. ${ }^{25}$ They found that the accuracy (RSD $\leq 10 \%$ ) of the sequential extraction procedure was generally good. and the sequential extraction procedure offered information on formation of each fraction for trace metals. Several possible problems can occur in sequential extractions due to conceptual and operational limitations. ${ }^{27}$ However. applications of the sequential extraction technique in the fields of engineering and the geosciences are convincing and sequential extraction procedures will continue to serve as important tools. ${ }^{30}$

The ultimate objective of this study is to determine the factors controlling mobility of copper. Secondary objectives are to fractionate copper solid phases present in the copper mining wastes and to characterize the chemical and mineralogical texture of the solid phases. Steps that will be taken to answer the primary question include: (1) quantification of the pool size of labile copper in sediments and stamp sands: (2) determination of the environmental factors controlling the copper solid phase shift under the certain environmental conditions. The investigation will focus on the Gay stamp sands. surface sediments of Torch Lake. and the sediments and stamp sands of the Boston Creek wetland.

\section{Methodology}

Sample collection. Eight sediment samples were collected from the three contrasting sites of Torch Lake. Boston wetland and Gay. An Ekman dredge was used to take approximately $5 \mathrm{~cm}$ of the top sediments in Torch Lake at two sites (19 m and $15 \mathrm{~m}$ water depths). which were located approximately $800 \mathrm{~m}$ to the southeast from the shoreline near the town of Lake Linden. Two surface stamp sands were collected from the Boston wetland. For the Boston wetland sampling. a polyetlylene core sleeve $(5.08 \mathrm{~cm}$ diameter) was used to obtain the wetland sample $(30.5 \mathrm{~cm}$ water depth) at the northern edge of the wetland. At the Gay site. four surface stamp sand samples were collected near the different pond using a plastic scoop. All samples were inmediately placed in glass bottles and transported to the laboratory: They were stored in a refrigerator in the dark at 4 ${ }^{\circ} \mathrm{C}$ until analyzed to minimize microbiological alteration of the samples.

Analysis. For water content clean evaporation dishes were heated to $103-105^{\circ} \mathrm{C}$ for $1 \mathrm{~h}$ and stored in a desiccator until needed. The dishes were then weighed inmmediately before use. Well-mixed samples. $5 \mathrm{~g}$ each. were evaporated in the weighed dishes and dried in an oven at $103-105^{\circ} \mathrm{C}$ until a constant weight was obtained. Samples were cooled in a desiccator before weighing. To analyze the particle size distribution of the samples. four U.S. standard test sieves were employed: $12(1680 \mu \mathrm{m}) .20(840 \mu \mathrm{m}), 30(590 \mu \mathrm{m})$. and $40(420 \mu \mathrm{m})$ mesh. A dry'sieve analysis method for the Gay and the Boston stampsand samples was applied whereas a wet-sieve analy'sis method for the Torch Lake sediments was used due to caking while drying.

$\mathrm{X}$-ray diffraction (XDS $2000^{\mathrm{TM}}$ Scintag INC.) measurements were made on the Boston wetland sample. which had the highest copper carbonate and oxide fractions (Figure 2). A scan range of $5-70^{\circ} 2 \theta$ was used to examine the solid phases: step size was 0.03 degrees. and scan time was $10 \mathrm{~s}$ at each position. Samples of particle size less than 200 mesh were prepared by grinding in order to identify bulk solid phases. To identify the major and copper solid phases. the spectra of the possible major metals and copper solid phases were compared to X-ray diffraction spectra of the samples based on the previous compositional analysis and the origin of samples. ${ }^{31.32}$ A summary of the major and copper-bearing minerals in three experiment sites is shown in Table 1.

Sequential chemical extractions (SET) were used to deter- 


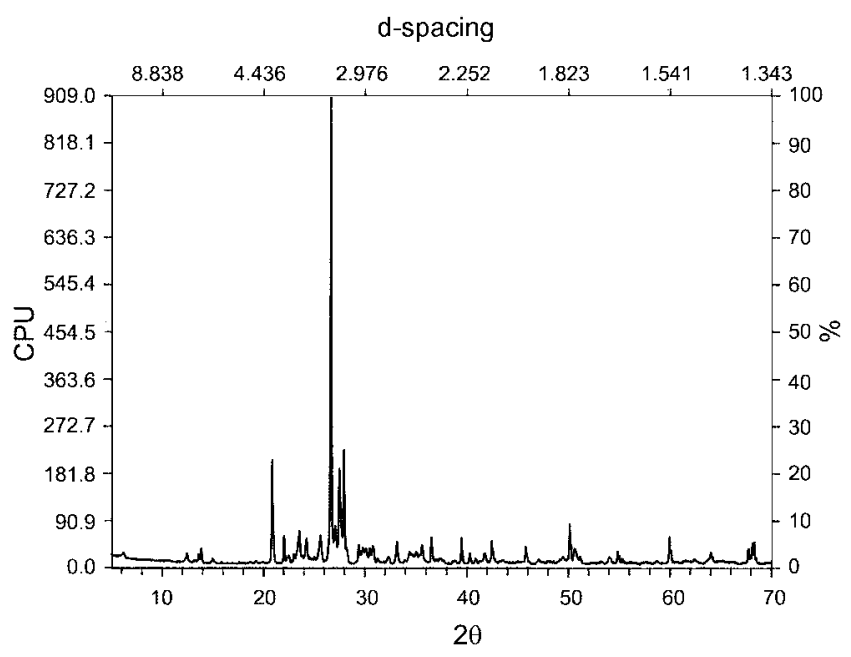

Figure 2. A typical X-ray diffraction pattern of a Boston wetland sample with a scan range of $5-70^{\circ} 2 \theta$, step size of 0.03 degrees, and scan time of 10 s at each position.

Table 1. Possible major and copper solid phases (Heinrich, 1976)

*Torch Lake \& Boston Wetland Sites

Possible Minerals of Red Rhyolite Possible Phases of Copper

Conglomerate

\begin{tabular}{|c|c|}
\hline Apatite group & Elemental Copper \\
\hline Hematite $\left(\mathrm{Fe}_{2} \mathrm{O}_{3}\right)$ & Azunite $\left(\mathrm{Cu}_{3}\left(\mathrm{CO}_{3}\right)_{2}(\mathrm{OH})\right.$ \\
\hline Orthoclase $\left(\mathrm{K}, \mathrm{Al}, \mathrm{Si}_{3} \mathrm{O}_{8}\right)$ & Malachite $\left(\mathrm{Cu}_{2} \mathrm{CO}_{3}\left(\mathrm{OH}_{2}\right)\right.$ \\
\hline Quartz $\left(\mathrm{SiO}_{2}\right)$ & Tenorite (CuO) \\
\hline Sanidine $\left(\mathrm{K}, \mathrm{Na}, \mathrm{AlSi}_{3} \mathrm{O}_{3}\right)$ & Chalcopyrite (CuFes. \\
\hline Toummaline group & Paramelaconite $\left(\mathrm{Cu}_{4} \mathrm{O}_{3}\right)$ \\
\hline \multirow[t]{3}{*}{ Calcite $\left(\mathrm{CaCO}_{3}\right)$} & Copper carbonate $\left(\mathrm{CuCO}_{3}\right)$ \\
\hline & Chry socolla ( $\mathrm{CuSiO}_{3} \cdot 2 \mathrm{H}_{2} \mathrm{O}$ \\
\hline & Covellite (CuS) \\
\hline
\end{tabular}

*Gay Site

Possible Minerals of Amvdaloidal Possible Phases of Copper Basalt

Albite $\left(\mathrm{Na}, \mathrm{Ca}, \mathrm{Si}, \mathrm{Al}_{4} \mathrm{O}_{8}\right)$

Augite $\left(\mathrm{Ca}, \mathrm{Fe}, \mathrm{Mg}, \mathrm{Si}_{2} \mathrm{O}_{6}\right)$

Orthoclase $\left(\mathrm{K}, \mathrm{Al}_{3}, \mathrm{Si}_{3} \mathrm{O}_{8}\right)$

Quartz $\left(\mathrm{SiO}_{2}\right)$

Calcite $\left(\mathrm{CaCO}_{3}\right)$

Hematite $\left(\mathrm{Fe}_{2} \mathrm{O}_{3}\right)$

Microcline $\left(\mathrm{K}, \mathrm{Al}_{2}, \mathrm{Si}_{3} \mathrm{O}_{3}\right)$

Biotite $\left(\mathrm{K}, \mathrm{Mg}, \mathrm{Si}_{2}, \mathrm{AlO}_{3}, \mathrm{OH}_{2}\right)$

Ilmenite $\left(\mathrm{Fe}, \mathrm{TiO}_{3}\right)$

Olivine $\left(\mathrm{Mg}_{2}, \mathrm{Fe}_{2}, \mathrm{SiO}_{4}\right)$

Muscovite $\left(\mathrm{K}, \mathrm{Al}_{2}, \mathrm{Si}_{4} \mathrm{O}_{10}, \mathrm{OH}_{2}\right)$

mine the relative abundances of five operationally defined copper fractions: exchangeable. carbonates oxides organic matter. and residual. The SET was slightly modified from Tessier's method: the reagents used for fraction 5 (residual) were modified to Aqua Regia ( $1: 1$ (v/v) mixture of hydrochloric acid and nitric acid) and hydrofluoric acid (HF) instead of perchloric acid and hydrofluoric acid. ${ }^{25}$ Approximately $2 \mathrm{~g}$ of dry samples were used for the initial extrac-

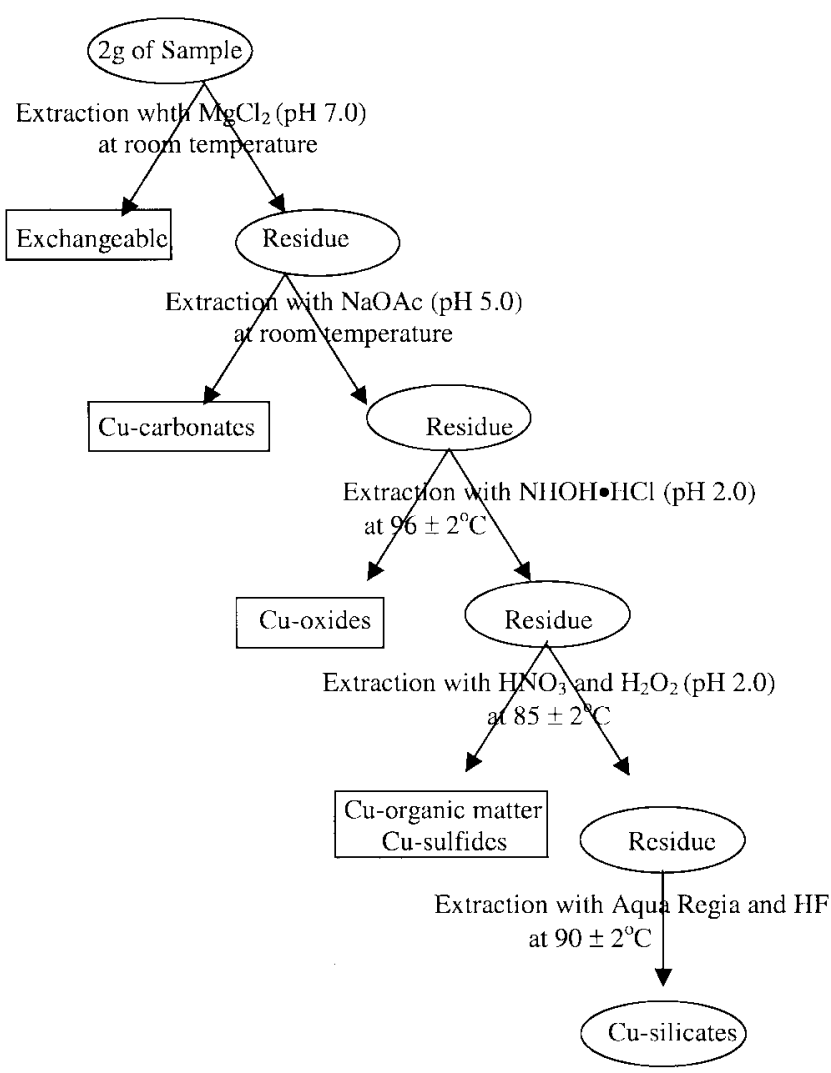

Figure 3. Experimental design of the sequential extraction technique for sediments and stamp sands (modified from Tessier et al. 1979)

tion. All extractions were performed in triplicate. The fractionation scheme (five steps of extractions) is outlined by the flow diagram in Figure 3.

High density polyethylene bottles $(60 \mathrm{~mL})$ were used for the sequential extraction. Between extraction steps. a separation of supernatant and solid material was effected by centrifuging (CPU-5000. Damon/IEC. Division) at $2000 \mathrm{rpm}$ for $30 \mathrm{~min}$. The supernatant was removed with a șringe after centrifuging and filtered with a $0.22 \mu \mathrm{m}$ membrane filter (Micron Separations. Inc). Deionized water used in preparing the stock solutions and for making the reagents for each extraction step was obtained from Milli-Q $Q^{\bar{R})}$ UV PLUS system (Millipore Co.). All glassware used for the experiments were previously soaked in $5 \%$ hydrochloric acid ( $\mathrm{v} / \mathrm{v})$ and rinsed three times with both distilled water and deionized water. All chemicals used in this study were reagent grade.

The SET was also applied to eight pure mineral samples obtained from the Seaman Mineral Museum at Michigan Teclunological University. These included copper carbonates (azurite and malachite), copper oxides (tenorite and cuprite). copper sulfides (chalcocite. covellite, and chalcopyrite). copper silicate (cluy socolla). elemental copper, and a mixture of pure minerals (elemental copper. malachite. tenorite. covellite. chrysocolla) and humic acid (Aldrich Co. reagent grade). The pure samples were used to examine selectivites of the reagents used in the SET for the pure solid phases and the mixture of them. SET was also applied to the mixture of pure 
minerals including elemental copper. malachite. tenorite. covellite cluysocolla. and humic material to compare the theoretical recovery with the experimental recovery of the pure mineral mixture and predicted recovery based on pure minerals. The composition of the mixture was $15.7 \%$ elemental copper. $15.7 \%$ malachite. $14.0 \%$ tenorite. $17.6 \%$ covellite. $12.0 \%$ chry socolla and $24.9 \%$ humic acid in dry weight.

To evaluate the optimum time for leaching the carbonate and Fe-Mn oxide fractions, the Boston wetland sample was repeatedly extracted for both fractions. For the carbonate fraction. samples were leached with $1 \mathrm{M} \mathrm{NaOAc}(\mathrm{pH} 5.0$. adjusted with $\mathrm{HOAc}$ ) for $48 \mathrm{~h}$. For the oxide fraction. samples were extracted with $0.04 \mathrm{M} \mathrm{NH}_{2} \mathrm{OH} \cdot \mathrm{HCl}$ in $25 \%$ (v/v) HOAc ( $\mathrm{pH} \mathrm{2.0)}$ and were then leached for $48 \mathrm{~h}$ with periodic sub-sampling to find an optimum leaching time for the oxide fraction. Total concentrations of calcium and copper for the carbonate fraction and total concentrations of iron and copper for the oxide fraction were measured.

To verify the results from the SET. a one-step extraction (OSE) was applied. Samples were digested with Aqua Regia $(1: 1(\mathrm{v} / \mathrm{v})$ mixture of nitric acid and hydrochloric acid) for $22 \mathrm{~h}$ at $90 \pm 2{ }^{\circ} \mathrm{C}$ after continuous agitation for $2 \mathrm{~h}$ at room temperature. After that hydrofluoric acid (HF) was added and leached for $24 \mathrm{~h}$ at $90 \pm 2{ }^{\circ} \mathrm{C}$ by the same process described above. After centrifuging the supernatant and the residue were separated using a $0.22 \mu \mathrm{m}$ membrane filter. The residue was washed with deionized water. and the supernatant and the deionized water used for washing the residue were combined and saved to measure the total concentration of copper.

Total concentrations of copper. iron. calcium. and manganese were determined by atomic absorption spectrophotometry (Perkin-Elmer 5000 AAS) using flame (5000 Automatic Burner Control). The standard addition method was applied to measure total concentrations of all metals in order to partially or wholly counteract the chemical and spectral interferences introduced by the sample matrix. Chemical interferences can be caused by anions like phosphate that form a thermally stable compound with calcium. To avoid this chemical interference during measurements of the total concentrations of calcium. $1 \%$ of lanthanum chloride $\left(\mathrm{LaCl}_{3}\right)$ solution was added to the samples. The detection limit. defined as the concentration of an element that produces an analytical signal equal to three times the standard deviation of the background signal, was calculated. Detection limits of copper for flame and electrothermal methods were $39 \mathrm{ppb}$ $(0.614 \mu \mathrm{M})$ and $0.385 \mathrm{ppb}(0.0061 \mu \mathrm{M})$, respectively.

\section{Results}

Water Content and Particle Size Distribution. Sediment samples have a wide range of water content and particle size distributions (Table 2). The sediment samples from Torch Lake have the highest water contents and have a high content of fine particles. The Boston wetland (Boston A) and Gay pond (Gay D) samples also have relatively high water content compared to the other samples. The sediment samples of Torch Lake consist mostly of the silt portion (i.e., more than $35 \%$ of the sample passing through 200 mesh). ${ }^{8}$ The predominate particle size of stamp sands at the Gay site is between 4 mesh and 30 mesh what is a mixture of gravel and coarse sand ${ }^{31}$ Boston wetland samples have a high content of coarse (bigger than Mesh 12) and fine (smaller than Mesh 40) particles whereas most of the Gay samples have medium size particles (between Mesh 20 and 40). According to the results. the higher the water content of a sample the higher the content of fine particles.

$\mathrm{Cu}$ and Major Minerals. Copper and major minerals of the Boston wetland samples were analyzed by powder X-ray diffraction. The result revealed that sanidine (potassium sodium aluminum silicate). orthoclase (potassium aluminum silicate). quartz (silicon dioxide). hematite (iron oxide). and calcite (calcium carbonate) are the major components of this conglomerate ore. These results are in agreenent with previous study of mineralogy from this region. ${ }^{32}$ Several copper solid phases (i.e., azurite, malachite. tenorite. cuprite. covellite. chalcopyrite. chalcocite and chry socolla) were expected to be present in the Boston sample based on bulk chemical analy sis. $^{\text {? }}$

The X-ray diffraction analysis for copper mineral phases revealed that two copper oxide minerals (cuprite and tenorite). one copper carbonate mineral (malachite), and one copper iron sulfide mineral (chalcopyrite) might exist in the stampsand sample. In addition, other copper minerals such as copper carbonate (azurite), copper oxides (paramelaconite). copper sulfides (chalcocite and covellite), and copper silicate (plancheite) could exist in the stamp sands. These minerals were not clearly identified because all peaks of known phases of copper minerals were covered by the noise of the $\mathrm{X}$-ray diffraction pattern. X-ray diffraction analy sis failed to identify clearly the copper solid phases in the natural mineral

Table 2. Water contents and particle size distribution

\begin{tabular}{|c|c|c|c|c|c|c|c|c|}
\hline Sampling Sites & Boston A & Boston B & Gay A & Gay $B$ & Gay $\mathrm{C}$ & Gay D & Torch A & Torch B \\
\hline $\mathrm{H}_{2} \mathrm{O}(\%)$ & 25.8 & 4.0 & 9.8 & 4.1 & 0 & 29.5 & 67.4 & 71.5 \\
\hline \multicolumn{9}{|l|}{ Mesh Size } \\
\hline 12 & 18.3 & 28.0 & 4.4 & 4.1 & 100 & 8.4 & - & - \\
\hline 20 & 19.9 & 29.3 & 32.1 & 59.0 & - & 29.9 & 0.8 & 0.6 \\
\hline 30 & 11.6 & 11.8 & 24.3 & 24.1 & - & 28.4 & 0.2 & 0.3 \\
\hline 40 & 10.4 & 8.1 & 22.1 & 8.7 & - & 20.2 & 0.3 & 0.3 \\
\hline Bottom & 39.8 & 22.8 & 17.2 & 4.2 & - & 13.1 & 98.7 & 98.8 \\
\hline
\end{tabular}


systems because of the detection limitation and both peak shifts and interferences caused by the extremely complicated composition.

Wet Chemical Analysis. A NIST standard reference material (SRM 3172a: Multielement Mix B-1 Standard Solution) was used to make calibration standard solutions. and the solutions were then analyzed by flame atomic absorption spectroscopy (AAS). Each sample was measured three times. A 3 ppm standard was accurate to within $5.7 \%$ of the NIST standard concentration. The other NIST standard reference material (SRM 2704: Buffalo River Sediment). containing $0.099 \pm 0.005 \mathrm{mg} / \mathrm{g}$ of copper. was also analyzed after SET and OSE analyses. and the concentration of total copper was measured by AAS. Concentrations of total copper recorded in the triplicate samples were $0.11 \mathrm{mg} / \mathrm{g}$ from both methods (SET and OSE) withm $4.2 \%$ error. Analysis of blank sample (extraction blanks) generally yielded a concentration around $0.45 \mathrm{ppm}$, a value lower than the standard deviation for total copper in all samples.

From the leaching of the copper carbonate fraction. an extraction time of $24 \mathrm{~h}$ was adopted because the dissolution of copper in stamp sands was completed within $24 \mathrm{~h}$. whereas calcium was extracted within $6 \mathrm{~h}$. For the oxide fraction. a leachung tume of 18 hours was adopted because all reducible copper in stamp sands was extracted after $18 \mathrm{~h}$ whereas the iron concentration contunuously increased with time. Total concentrations of copper measured by the sequential extraction teclunique and the one step extraction method were comparable to each other (Figure 4). Concentrations of copper obtained from the one-step extraction were slightly higher than those of copper from the sequential extraction technique. except the Gay C sample.

The results of SET for pure minerals revealed that only 50 $93 \%$ of pure copper carbonate minerals (azurite and malachite) were recovered in the carbonate fraction. and only 25 $40 \%$ of pure copper oxides (tenorite and cuprite) were recovered in the oxide fraction. Approximately $60 \%$ of the

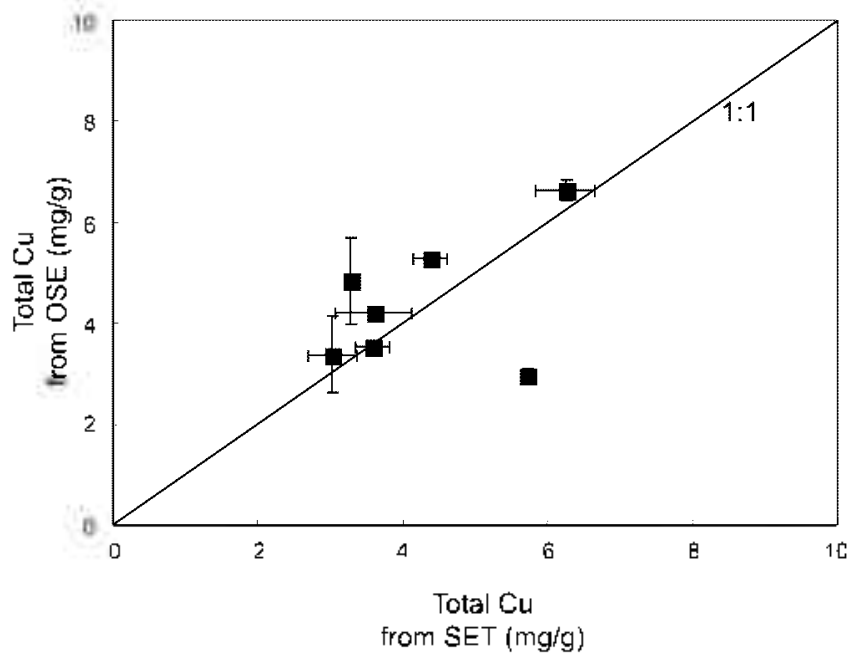

Figure 4. Correlation between SET and OSE (ETror bars represent the standard deviations of total $\mathrm{Cu}$ from SET and OSE are 4.2$29.2 \%$ and $1.8-36 \%$, respectively). copper oxide minerals. which should be recovered in the oxide fraction. were instead extracted in the carbonate fraction. Elemental copper was also extracted in these steps. $60 \%$ in the carbonate fraction and $40 \%$ in the oxide fraction. Copper sulfides ( $c a .80-90 \%$ of chalcocite. covellite. and chalcopyrite) were recovered primarly in the residual fraction. Around $80 \%$ of copper silicate (chrysocolla). which should be extracted in the residual fraction. was extracted in the oxide fraction. There is a large difference between the experimental and the theoretical recoveries of copper for all fractions except the exchangeable fraction from the pure mineral mixture (Figure 5a and 5b). The experimental recoveries of copper from the pure mineral mixture are $0.5 \%$ for the exchangeable fraction. $33 \%$ for the carbonate fraction. $36.1 \%$ for the oxide fraction. $5.8 \%$ for the organic matter fraction. and $24.7 \%$ for the residual fractions whereas those expected from theoretical calculation are $0 \%$ for exchangeable. $15.1 \%$ for carbonate. $21.4 \%$ for oxide. $55.5 \%$ for organic matter. and $8 \%$ for residual. The difference in the copper recovery between the experimental and the predicted values was in the carbonate and oxide fractions. However. the predicted recoveries of copper for each fraction (exchangeable: $0.5 \%$ : carbonate: $48.4 \%$ : oxide: $29.9 \%$ : organic matter: $1.4 \%$ : residual: $19.3 \%$ ) based on pure minerals were close to the experimental recovery of the pure mineral mixture.

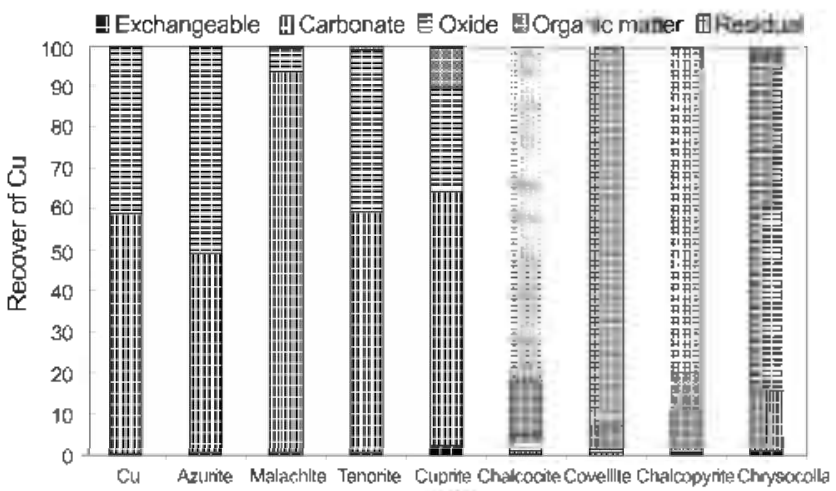

(a)

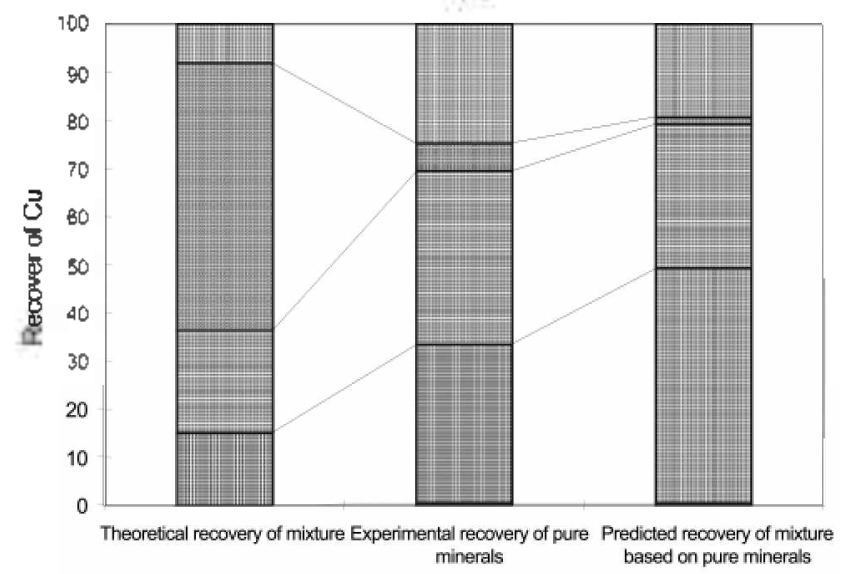

(b)

Figure 5. (a) Analysis of pure minerals by SET. (b) Comparison of experimental and predicted recoveries of pure mineral from a mixture with theoretical recovery: 
Table 3. Results from sequential extraction technique and one-step extractions for all samples

\begin{tabular}{|c|c|c|c|c|c|c|c|c|c|c|c|c|}
\hline Samples & \multicolumn{2}{|l|}{ Boston A } & \multicolumn{2}{|l|}{ Boston B } & \multicolumn{2}{|l|}{ Gay A } & \multicolumn{2}{|l|}{ Gay C } & \multicolumn{2}{|l|}{ Gay D } & \multicolumn{2}{|l|}{ Torch B } \\
\hline \multicolumn{13}{|l|}{ A. Sequential Extraction } \\
\hline Fraction & Conc. $(\mathrm{mg} / \mathrm{g})$ & $\%$ & Conc. $(\mathrm{mg} / \mathrm{g})$ & $\%$ & Conc. (mig/g) & $\%$ & Conc. $(\mathrm{mg} / \mathrm{g})$ & $\%$ & Conc. $(\mathrm{m} \mathrm{g} / \mathrm{g})$ & $\%$ & Conc. $(\mathrm{mg} / \mathrm{g})$ & $\%$ \\
\hline \multicolumn{13}{|c|}{ Total Copper Concentration } \\
\hline $\begin{array}{l}\text { 1) Exchangeable } \\
\text { STD } \\
\text { 2) Carbonate } \\
\text { STD } \\
\text { 3) Oxide } \\
\text { STD } \\
\text { 4) Organic Matter } \\
\text { STD } \\
\text { 5) Residual } \\
\text { STD } \\
\text { Total (sum of } 1-5 \text { ) } \\
\text { STD }\end{array}$ & $\begin{array}{l}2.9 \times 10^{-1} \\
2.7 \times 10^{-2} \\
9.5 \times 10^{-1} \\
6.1 \times 10^{-2} \\
1.0 \times 10^{-1} \\
1.9 \times 10^{-2} \\
2.0 \times 10^{-1} \\
2.1 \times 10^{-2} \\
8.4 \times 10^{-1} \\
5.8 \times 10^{-2} \\
3.3 \times 10^{0} \\
1.4 \times 10^{-1}\end{array}$ & $\begin{array}{l}6.10 \\
25.6\end{array}$ & $\begin{array}{l}1.2 \times 10^{-2} \\
2.0 \times 10^{-3} \\
2.3 \times 10^{0} \\
1.8 \times 10^{-1} \\
1.7 \times 10^{0} \\
3.5 \times 10^{-1} \\
2.8 \times 10^{-1} \\
5.9 \times 10^{-2} \\
2.0 \times 10^{0} \\
3.0 \times 10^{-1} \\
6.2 \times 10^{0} \\
8.2 \times 10^{-1}\end{array}$ & 0.20 & $\begin{array}{l}3.0 \times 10^{-3} \\
1.0 \times 10^{-3} \\
7.7 \times 10^{-1} \\
1.2 \times 10^{-2} \\
1.4 \times 10^{0} \\
3.6 \times 10^{-1} \\
9.9 \times 10^{-2} \\
7.5 \times 10^{-2} \\
7.6 \times 10^{-1} \\
2.3 \times 10^{-1} \\
3.0 \times 10^{0} \\
6.6 \times 10^{-1}\end{array}$ & 0.10 & $\begin{array}{l}5.0 \times 10^{3} \\
2.2 \times 10^{-2} \\
1.0 \times 10^{0} \\
5.4 \times 10^{-1} \\
4.1 \times 10^{0} \\
5.7 \times 10^{0}\end{array}$ & \begin{tabular}{|l|}
0.10 \\
0.40 \\
17.7 \\
9.40 \\
72.4
\end{tabular} & $\begin{array}{l}1.9 \times 10^{-1} \\
5.0 \times 10^{-3} \\
2.0 \times 10^{0} \\
5.8 \times 10^{-2} \\
1.4 \times 10^{0} \\
2.0 \times 10^{-1} \\
1.1 \times 10^{-1} \\
5.0 \times 10^{-3} \\
7.1 \times 10^{-1} \\
1.3 \times 10^{-1} \\
4.4 \times 10^{0} \\
4.6 \times 10^{-1}\end{array}$ & 4.20 & $\begin{array}{l}3.9 \times 10^{-1} \\
2.8 \times 10^{-1} \\
1.1 \times 10^{0} \\
4.8 \times 10^{-1} \\
7.0 \times 10^{-1} \\
1.6 \times 10^{-1} \\
1.4 \times 10^{0} \\
1.4 \times 10^{-1} \\
2.9 \times 10^{-1} \\
5.7 \times 10^{-2} \\
3.6 \times 10^{0} \\
1.1 \times 10^{0}\end{array}$ & \\
\hline \multicolumn{13}{|c|}{ Total Calciunn Concentration } \\
\hline $\begin{array}{l}\text { 2) Carbonate } \\
\text { STD } \\
\text { 3) Oxide } \\
\text { STD } \\
\end{array}$ & $\begin{array}{l}3.6 \times 10^{0} \\
2.9 \times 10^{-1} \\
1.2 \times 10^{0} \\
8.1 \times 10^{-2} \\
\end{array}$ & & $\begin{array}{l}8.4 \times 10^{1)} \\
5.4 \times 10^{-1} \\
1.6 \times 10^{1} \\
1.6 \times 10^{-1}\end{array}$ & & $\begin{array}{l}1.2 \times 10^{1} \\
2.2 \times 10^{11} \\
3.0 \times 10^{11} \\
4.3 \times 10^{-2}\end{array}$ & & $\begin{array}{l}2.2 \times 10^{0} \\
2.6 \times 10^{0}\end{array}$ & & $\begin{array}{l}4.1 \times 10^{-1} \\
1.3 \times 10^{-2} \\
2.3 \times 10^{-1} \\
3.3 \times 10^{-2}\end{array}$ & & $\begin{array}{l}5.4 \times 10^{-1} \\
1.8 \times 10^{-1} \\
1.1 \times 10^{11} \\
2.1 \times 10^{-1}\end{array}$ & \\
\hline \multicolumn{13}{|l|}{ Total Iron Concentration } \\
\hline $\begin{array}{l}\text { 3) Ovide } \\
\text { STD } \\
\text { 4) Organic Matter } \\
\text { STD }\end{array}$ & $\begin{array}{l}4.5 \times 10^{0} \\
4.6 \times 10^{-2} \\
5.4 \times 10^{-2} \\
7.0 \times 10^{-3}\end{array}$ & & $\begin{array}{l}1.7 \times 10^{0} \\
7.2 \times 10^{-2} \\
2.3 \times 10^{-2} \\
3.0 \times 10^{-3}\end{array}$ & & $\begin{array}{l}3.1 \times 10^{0} \\
1.4 \times 10^{-1} \\
6.5 \times 10^{-1} \\
7.0 \times 10^{-3}\end{array}$ & & $\begin{array}{l}4.9 \times 10^{0} \\
2.6 \times 10^{-1}\end{array}$ & & $\begin{array}{l}2.9 \times 10^{0} \\
6.6 \times 10^{-1} \\
5.7 \times 10^{-1} \\
4.3 \times 10^{-1}\end{array}$ & & $\begin{array}{l}1.3 \times 10^{1} \\
3.0 \times 10^{-1} \\
2.0 \times 10^{-1} \\
2.6 \times 10^{-2}\end{array}$ & \\
\hline \multicolumn{13}{|c|}{ Total Manganese Concentration } \\
\hline $\begin{array}{l}\text { 3) Oxide } \\
\text { STD }\end{array}$ & $\begin{array}{l}5.8 \times 10^{-2} \\
1.0 \times 10^{-3}\end{array}$ & & $\begin{array}{l}4.9 \times 10^{-\hat{-}} \\
2.0 \times 10^{-3}\end{array}$ & & $\begin{array}{l}1.3 \times 10^{-1} \\
2.0 \times 10^{-3}\end{array}$ & & 0.142 & & $\begin{array}{l}1.8 \times 10^{-1} \\
1.7 \times 10^{-2}\end{array}$ & & $\begin{array}{l}2.6 \times 10^{-1} \\
1.1 \times 10^{-2}\end{array}$ & \\
\hline \multicolumn{13}{|l|}{ B. One Step Extraction } \\
\hline $\begin{array}{l}\text { Copper Concentration } \\
\text { STD }\end{array}$ & $\begin{array}{l}4.8 \times 10^{0} \\
1.7 \times 10^{0}\end{array}$ & & $\begin{array}{l}6.6 \times 10^{0} \\
4.1 \times 10^{-1} \\
\end{array}$ & & $\begin{array}{l}3.4 \times 10^{0} \\
1.5 \times 10^{0}\end{array}$ & & $\begin{array}{l}3.0 \times 10^{0} \\
2.6 \times 10^{-1}\end{array}$ & & $\begin{array}{l}5.3 \times 10^{0} \\
2.1 \times 10^{-1}\end{array}$ & & $\begin{array}{l}4.2 \times 10^{0} \\
2.1 \times 10^{-1}\end{array}$ & \\
\hline
\end{tabular}

The results of the sequential extraction (SET) for all samples are shown in Table 3 . These results are obtained by triplicate determinations. Concentrations of total copper as measured by SET have a range of $3.0-6.3 \mathrm{mg} / \mathrm{g}$ with standard deviations of $0.14-1.05 \mathrm{mg} / \mathrm{g}$. Total copper concentrations as measured by OSE have a range of $2.9-6.6 \mathrm{mg} / \mathrm{g}$ with standard deviations (0.06-1.74 mg/g). Concentrations of copper in Gay $\mathrm{C}$ and Boston $\mathrm{B}$ samples. which have a large portion of copper in the residual fraction. are relatively high (5.7 and $6.2 \mathrm{mg} / \mathrm{g}$ ) compared to other samples. The concentrations of copper found in each fraction were $0.001-0.39 \mathrm{mg} / \mathrm{g}$ for the exchangeable fraction. $0.022-2.26 \mathrm{mg} / \mathrm{g}$ for the carbonate fraction $0.703-1.65 \mathrm{mg} / \mathrm{g}$ for the oxide fraction. $0.09-0.28$ $\mathrm{mg} / \mathrm{g}$ for the organic matter fraction. and $0.291-2.03 \mathrm{mg} / \mathrm{g}$ for the residual fraction.

\section{Discussion}

Copper and Major Minerals in Stamp Sands. The major mineral phases can affect the water quality of natural systems by releasing other competing metals and inorganic ligands. The origin of the stamp sands dumped in the northern part of Torch Lake and the Boston Pond and wetland areas is red rhyolite conglomerate. ${ }^{33}$ Major minerals of red rhyolite conglomerate include the apatite group. hematite $\left(\mathrm{Fe}_{2} \mathrm{O}_{3}\right)$, orthoclase $\left(\mathrm{KAlSi}_{3} \mathrm{O}_{8}\right)$, quartz $\left(\mathrm{SiO}_{2}\right)$, sanidine $(\mathrm{K}$. $\mathrm{Na} . \mathrm{AlSi}_{2} \mathrm{O}_{3}$ ). and the tourmaline group. ${ }^{7.32} \mathrm{X}$-ray diffraction analyses of Boston wetland stamp sands show that calcite. quartz. hematite. orthoclase and one of the sanidine minerals (potassium aluminum silicate) are present as major minerals in the stamp sands. However. minerals (magniotriplite. sarkinite belovite etc.) belonging to the apatite and tourmaline groups were not identified. The most important major mineral found in stamp sands is calcite what influences concentrations of carbonate species in natural systems. Therefore. calcite can affect the formation of copper minerals on the surface of stamp sands and the water quality of surface waters. 
The Allouez Conglomerate ore lodes by stamping the parent rock. The load was distinguished by dark veins of calcite containing chalcocite $\left(\mathrm{Cu}_{2} \mathrm{~S}\right)$, and native copper $\left(\mathrm{Cu}^{\circ}\right)$. and traces of cuprite $\left(\mathrm{Cu}_{2} \mathrm{O}\right)$, malachite $\left(\mathrm{Cu}_{2} \mathrm{CO}_{3}(\mathrm{OH})_{2}\right)$, and chrysocolla $\left(\mathrm{Cu}_{2} \mathrm{SiO}_{3} \cdot 2 \mathrm{H}_{2} \mathrm{O}\right)$ were found on the poor rock piles ${ }^{33}$ Also tenorite $(\mathrm{CuO})$ and copper carbonate $\left(\mathrm{CuCO}_{3}\right)$ might be expected due to the oxidation of native copper exposed to the air and water and the precipitation of copper carbonate in the wetland area. ${ }^{\text {" }}$ The X-ray diffraction analysis for copper solid phases indicated that copper oxides (cuprite and tenorite). copper carbonate (malachite) and copper iron sulfide (chalcopyrite) could be present in the Boston stampsand sample taken near Boston road. These results are similar to the previous report. ${ }^{11.33}$ But. no copper mineral could be unambiguously identified due to the low copper content and the complexity or heterogeneity of the samples. The content of copper was too low (less than $0.1 \%$ ) to be detected by X-ray diffraction: as a result. the X-ray signals of copper solid phases were covered by the background signal. ${ }^{31}$ The results imply that X-ray diffraction is not a proper qualitative analytical method to analyze the copper solid phases in stamp sands that contain very low concentrations of copper.

Fractionation of Solid Copper Phase. Sequential extraction for pure minerals and a mixture of pure minerals showed that recovery of individual minerals was not consistent with the theoretical phase separation but agreed with the predicted recovery based on single mineral extractions (Figure $5 \mathrm{a}$ and $5 \mathrm{~b}$ ). Several reasons might explain the discrepancy between the theoretical recovery and SET results for pure minerals and their mixtures. Clearly the reagents used in this work are not able to selectively destroy single phases without any solubilization of the others ${ }^{27}$ Other limitations of SET included the inability of SET to simulate the actual condition of natural processes and transformation of solid forms during sample pretreatment and preservation. Moreover. the SET results reflect the chemical properties of elements rather than their actual association with mineral phases. Two conclusions based on the results of SET for pure minerals and their mixture are: (1) the amount of the copper carbonate fraction can be overestimated because some oxide minerals and some elemental copper are coextracted with copper carbonates. and (2) the amount of the oxidizable fraction can be underestimated due to the dissolution of the copper sulfide minerals in the residue fraction. However. SET is still valuable for the fractionation of solid copper phases in stamp sands because SET can separate non-residual fractions from the residual fraction and speciate semi-quantitatively each of the non-residual fractions as well.

Leaching-time experiments for the copper carbonate and oxide fractions give further insights into the distribution of copper minerals in the stampsand and the structure of stampsand particles. The concentration of copper in the carbonate fraction increased continuously with increasing extraction time even after all $\mathrm{Ca}$ was extracted (Figure 6a). Also. there is no correlation between the total concentrations of calcium and copper (Figure 6b): if copper carbonate minerals were
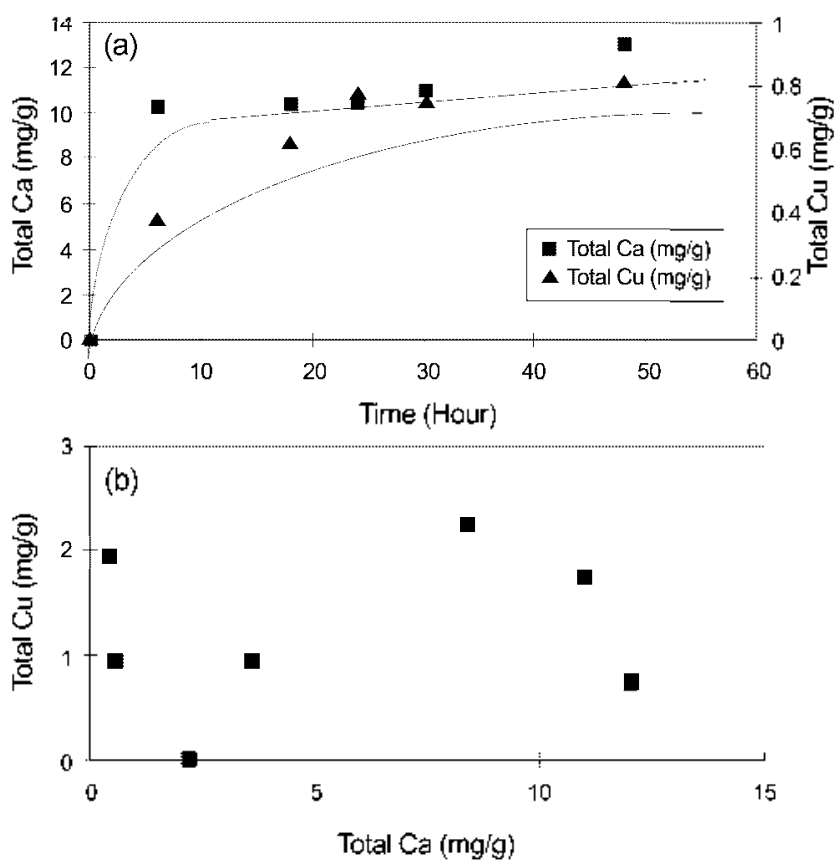

Figure 6. (a) Leaching time experiment for the carbonate fraction. (b) Relation between total concentrations of $\mathrm{Cu}$ and $\mathrm{Ca}$ in the carbonate fraction.
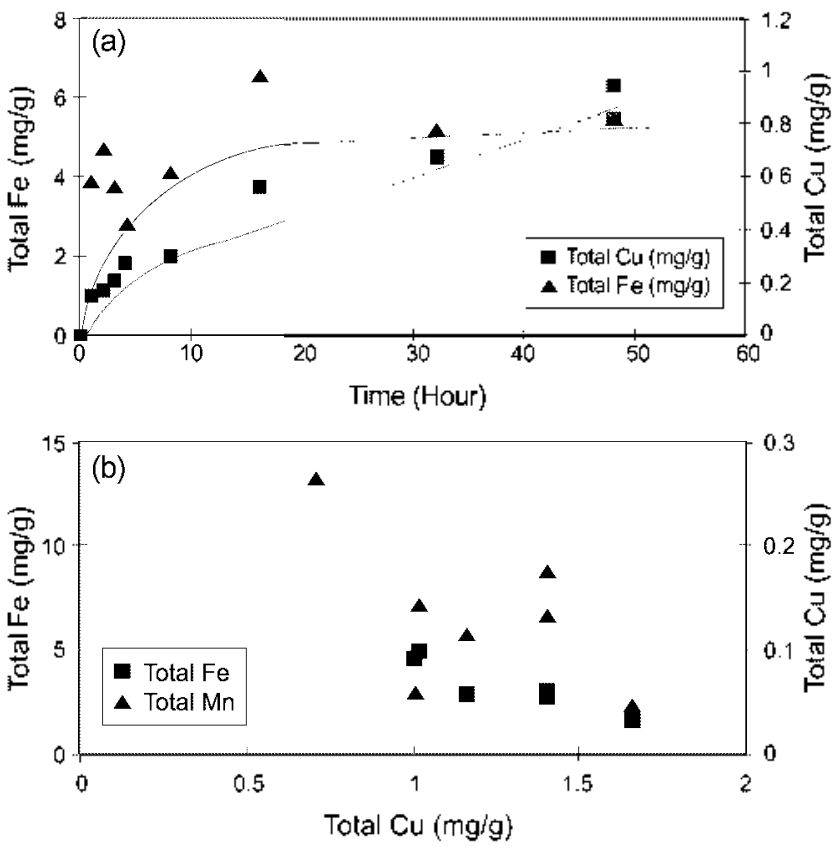

Figure 7. (a) Leaching time experiment for the oxide fraction. (b) Correlation between total concentrations of $\mathrm{Cu}, \mathrm{Fe}$, and $\mathrm{Mn}$ in the oxide fraction.

bound to calcium minerals existing only on the surface of the particles. concentrations of copper should increase with increasing concentrations of calcium. In contrast, the concentration of copper reaches a maximum after about $18 \mathrm{~h}$ while the concentration of iron continuously increases with extraction time in the hydroxylamine extraction (Figure 7a). An inverse correlation between total concentration of iron and copper is also found in the oxide fraction (Figure $7 \mathrm{~b}$ ). These 
results indicated that the copper oxide minerals occur as coatings on the surface of iron oxide minerals present in the stamp sands: copper does not change in concentration. whereas iron concentrations increase with increasing thickness of the iron oxide lay'er.

Sequential extractions have shown that copper solid phases (such as copper carbonates. copper oxides. copper-organic matter complexes. and copper silicates) existing in the sediments and stampsands can be determined qualitatively and semi-quantitatively using the SET. but individual copper minerals can not be identified. Most copper in British soils and sediments at Quebec. Canada. are found as copperorganic matter compounds (20-40\%) copper oxides (15$20 \%$ ). and copper silicates $(30-60 \%)$. $^{25}$ In contrast our SET (Figure 8) indicated that most of the copper present in the stamp sands at the Boston wetland and Gay sites is found as copper carbonate and oxide minerals ( $c a .50-80 \%$ ) with small amounts of exchangeable copper. copper organic matter complexes or copper sulfides ( $c a .5-10 \%$ ). and with moderate amounts of copper silicates ( $c a .7-30 \%$ ). Copper in Torch Lake sediments appears to be dominated by copperorganic complexes. but our results are in general agreement with previous studies that found copper carbonates (cuprite. malachite) copper sulfide (chalcocite). copper silicate (chrysocolla). ${ }^{33}$ and copper oxide (tenorite). ${ }^{1]}$ This result suggests that most of the copper in sediments and stamp sands in Boston wetland and the Gay area is related to the oxidation of native copper and the precipitation of copper carbonates. whereas the copper present in sediments of Torch Lake is related to biological processes in the lake.

Pool Size of Labile Copper. The ability of a particular complex to engage in reactions that result in replacing one or more ligands in its coordination sphere is called its lability (Cotton and Wilkinson. 1980). Lability is dependent on how fast the complexes react and exchange with other ligands rather than the stability (binding strength) of the complexes. In natural systems. however labile copper can be defined as that fraction of copper in sediments. which can dissolve and react with the dissolved constituents in the surface water in time periods determined by water residence times. Copper minerals in natural systems can be divided into two fractions: residual and non-residual copper fractions. The residual copper fraction consists primarily of copper incorporated into crystalline silicates. which are unavailable by either biological or diagenetic processes over long-time periods. ${ }^{27}$ The non-residual copper fraction consists of several different fomms of copper such as exchangeable copper. copper carbonates. copper oxides and copper adsorbed on iron and manganese oxides. copper sulfides and copper bound to organic matter. Therefore. some of the non-residual fraction. the exchangeable copper (weakly bound to the surface of particles). copper carbonate and oxide minerals. and copper organic matter fraction (thermodynamically stable but reacts with the dissolved copper species in the water columun). can be considered as labile copper with respect to water residence times. These water residence times depend on environmental characteristics of the sampling sites.
SET indicated that the pool size of labile copper (nonresidual fraction) is approximately $50-60 \%$ of the total concentration of copper in the sediments and stamp sands around the Keweenaw Peninsula (Torch Lake: ca. 90\%. Boston wetland: $c a .75-80 \%$. Gay site: $c a .25-85 \%$ ). Carbonate and oxide fractions are the largest pools of labile copper ( $\mathrm{ca}$. $45-70 \%$ ) in two sites (Boston and Gay sites), whereas the organic matter (oxidizable) fraction is the largest reservoir (ca. 30\%) in Torch Lake. The pool size of labile copper in the sediment of Torch Lake and stamp sands of Boston wetland and Gay may be underestimated or overestimated by SET with respect to water residence times. In the Torch Lake șistem. most of non-residual fractions $(60 \%)$ are considered to be labile copper because water residence time of Torch Lake is about 1 year. However, the "organic matter" (oxidizable) fraction can be underestimated by copper sulfide minerals recovered in the residual fractions. The pool size of labile copper (half of the carbonate fraction) at Boston Creek and wetland may be overestimated by SET because the water residence time of the Boston area is on the order of hours. which is shorter than the leaching time for the carbonate fraction $(48 \mathrm{~h})$. The Gay sites have water residence times ranging from hours to days. Around one third of the pool size of labile copper may be overestimated in the carbonate fraction except for the Gay $\mathrm{C}$ sample. Therefore the actual pool size of labile copper in stamp sands can be assumed to be approximately $60 \%$ for Torch Lake. $55-60 \%$ for the Boston wetland area. and $50-55 \%$ for the Gay sites

Factors Controlling Pool Size of Labile Copper: There are several factors affecting the pool size of labile copper such as the speciation of solid copper phases. the particle size of stamp sands. and environmental site factors. The relative abundances of copper solid phases and the particle size distribution of stamp sands are related to the distribution of different copper foms on the surface of stampsand particles. The environmental site factors (hydrologic setting. biogeological characteristics. physico-chemical conditions. and diagenetic processes) influence the surface composition of stampsand particles so that they can change the magnitude of labile copper in stanp sands.

The fractionation of solid copper phases provides infor-

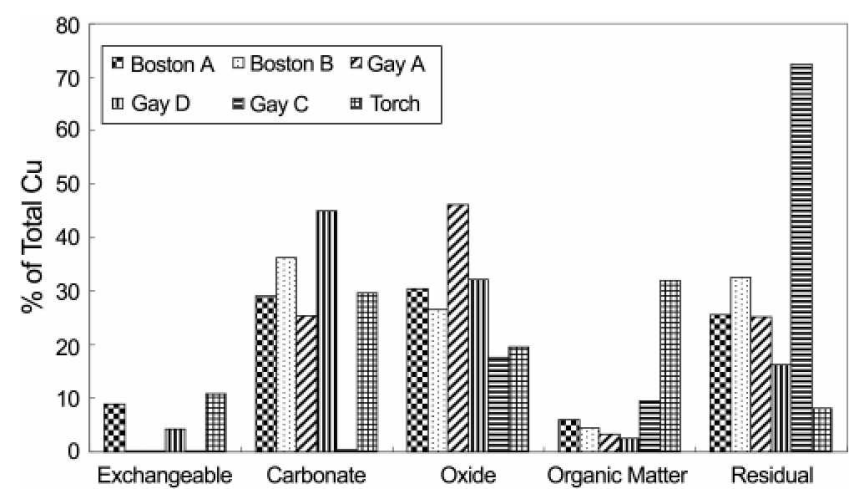

Figure 8. Distribution of copper in sediment and stamp sand sample. 


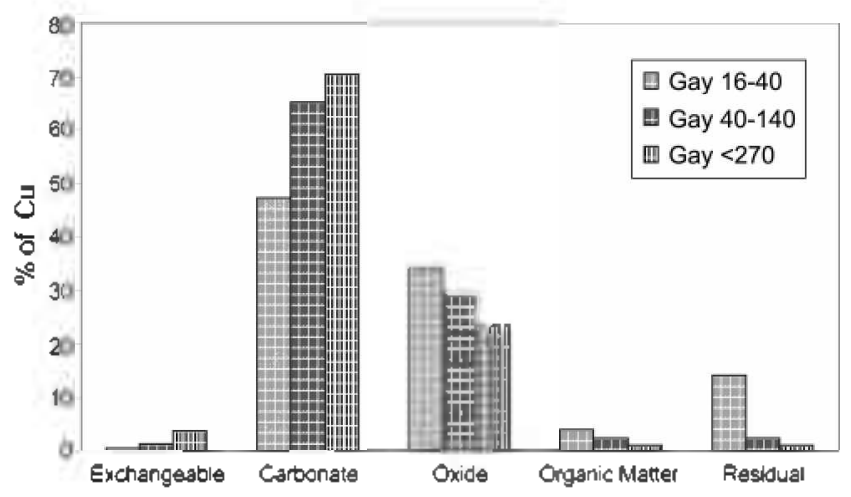

Figure 9. Total copper concentrations of each fraction with respect to particle size of Gay stampsand samples. Gay 16-40: the range of particle size is between 16 and 40 mesh, Gay $40-140$ : the range of particle size is between 40 and 140 mesh, Gay 270: particle size is less than 270 mesh.

mation on stampsand particle structure. The leaching time experiment results (Figure 6 and 7) suggest that the residual copper fraction is coated with $\mathrm{Fe}$ - and Mn-oxides. carbonates. and organic matter. The pool size of labile copper depends on the abundance of non-residual fractions present on the surface of the particles. Therefore, the distribution of nonresidual copper fractions on the surface of and inside stampsand particles is one of the factors affecting pool size of labile copper in stamp sands.

The pool size of labile copper is influenced by the particle size distribution in stamp sands. As particle size decreases. the specific area increases. and copper bound to carbonate and oxide fractions increases (i.e. mostly present on the surface of the sediment and stampsand particle) (Figure 9). The result indicates that the capacity for metal binding to sediments and stampsand samples depends on the ratio of surface area to volume. Therefore. particle size is one of the most important environmental parameters. which regulates the pool size of labile copper in sediments and stamp sands.

Environmental site factors are also important for the pool size of labile copper in sediments and stamp sands. The surface and pore water residence time depends on the incoming and outgoing flow rates and the volume of the natural systems. For example, the surface water residence time of Torch Lake is approximately one year. ": which is long compared to the time scale of the extraction experiments in the laboratory (less than $24 \mathrm{~h}$ ). A substance labile over the timeframe of the laboratory extraction would also be labile in the lake. In contrast the surface water residence time of streams or small creeks is very short (assumed to be less than $\mathrm{l} \mathrm{h}$ in Boston (reek), and the pool size of labile copper in those areas might be overestimated by the laboratory extractions of longer duration. The copper carbonate fraction does apparently increase with increasing water contents of stamp sands at Gay (Figure 10)

The magnitude of each labile copper phase varies with the different biogeological characteristics (oceans. lake. wetland. and streams) because those sites have different contents and sort of metal and organic matter. and different factors are

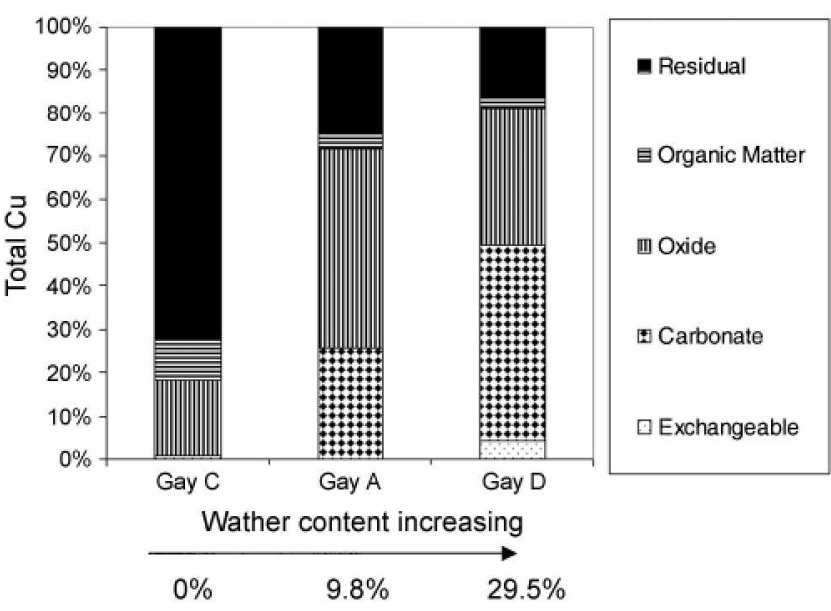

Figure 10. \% change of total copper at each fraction with water contents of stampsand samples from Gay

regulating metal transport processes and particle settling. In lake systems. biogenic organic particles ${ }^{34}$ play a dominant role in binding trace metals and transferring them into the sediments whereas the transport of micronutrients $s^{35}$ and metals $^{36 i}$ in streams are regulated by hydrologic. biologic. and chemical processes.

The physicochemical conditions of sediments (oxic or anoxic conditions) and diagenetic processes can also change the composition of copper solid phases in sediment particles. For example. the effects of redox conditions and weathering processes on the copper distribution in the Filson Creek fen have been studied, and approximately $40-50 \%$ of the copper in oxidized zones was associated with organic matter. and the remaining copper was distributed between the oxide. sulfide. and residual fractions. ${ }^{37}$ Weathering processes change the distribution of copper with depth and transform copper from one fraction to other fractions. All the evidence ascribed above indicates that the pool size of copper in sediments and stamp sands change with several factors acting on natural systems. and the factors contribute to the complexity of the sediment and stampsand particles.

\section{Conclusions}

Copper and major minerals in the stamp sands were identified by X-ray diffraction. Calcite. quartz, hematite, orthoclase. and sanidine minerals were present as major minerals in the stamp sands at wetland areas. Two copper oxide minerals (cuprite and tenorite), one copper carbonate mineral (malachite). and one copper iron sulfide mineral (chalcopyrite) might exist in the stampsand sample. In addition. other copper minerals such as copper carbonate (azurite), copper oxides (paramelaconite), copper sulfides (chalcocite and covellite). and copper silicate (plancheite) could exist in the stamp sands.

The pool size of labile copper has been found to be approximately $70 \%$ for Torch Lake. $55-60 \%$ for the Boston wetland area. and $50-55 \%$ for the Gay sites of total copper concentration of stamp sands (3-6 mg/g). In Torch Lake, the 
copper carbonate and copper-organic matter fractions are the largest reservoir of copper ( $c a .61 \%$ ). whereas the exchangeable and copper oxide fractions contributed less to concentrations of copper in sediments (10-20\%). In the Boston wetland and Gay sites. the copper carbonate and oxide fractions are the largest pools of copper ( $c a .45-60 \%$ ), and the exchangeable copper and copper-organic matter fractions are minor components.

Copper oxide mineral may occur as a coating on the surface of the stampsand particles. whereas copper carbonate minerals are present both at the surface of and inside the stampsand particles. The carbonate fraction increases with both decreasing particle size and water content of stamp sands. Envirommental parameters including particle size. water content. hỵdrologic setting. and diagenetic history were found to be factors controlling speciation of copper in the solid phase

\section{References}

1. Nriagu, I. O. Copper in the Entronment Part I: Ecological Cyching. John Wiley and Sons Inc.: New York. NY. 1979.

2. Barry. K. L.: Grout. J. A.: Levings. C. D.: Nidle. B. H.: Piercey. G. E. Camadian Jomal of Fisheries and Aquatic Sciences $\mathbf{2 0 0 0} .57$. $2032-2043$.

3. Bortleson. G. C.: Cox S. E.: Munn. M. D.: Schumaker. R. I.: Block, E. K. LS. Geological Surven Water-Supply Paper 2001, 1 120

4. Miller. G. C.: Lyons. W. B.: Davis. A. Eminon. Sci. Techoll 1996. 30.118A

5. Davison. W.: Hilton, J.: Lishman. I. P.; Pennington. W. Emiron. Sici. Technol. 1985, 19, 356.

6. Brown. K. P. Hosseinipour. E. Z. J. Entron. Sci. Healh 1991. A26. 157-203.

7. Babcock. L. L.: Spiroft. K. Inst. Mineral Res.: Michihan Technological University: 1970

8. Kerfoot, W. C: Lauster. G: Robbins. J. A. Limmology and Oceanograph 1994. 39.649-669.

9. Laberge. G. L. Geology of the Lake Superior Region: Geoscience press Ine.: Phoenic. AZ. 1994.

10. Lopez Diaz. J. M. M.S. Thesis: University of Wisconsin: 1973.

11. Leddy. D. G. Factors Confrolling Copper (II) Concentrations in the Keweenaw Waterwas Office of Water Recourses Research: Michigan Technological University: Holnghton. 1973.

12. Cusack, C. C.: Mihelcic, I. R. Jownat of Great Lakes Research $1999,25,735-743$

13. Nriagu. J. O. Copper in the Enironment Part II: Heallh Effects: John Wiley and Sons Inc.: New York. 1979.

14. Stumm. W: Morgan. J. J. Aquatic Chemistra 3rd ed.: John Wiely
\& Sons: New York, 1996

15. Anderson. B. S.; Hunt J. W.: Philips, B. M.; Fairly, R.; Puckett. H. M.: Stephenson. M.: Taberski. K.: Newnant. J.: Tjeerdema. R. S Harine Enimonnental Research 2001. 51. 191-221.

16. Malueg. K. W.: Schuytema. G. S.: Gakstatter. T. H.: Krawczy. K. D. F. Entromental Toxicology and Chemistry 1984, 3. 279-291.

17. Stauber. J. L.: Benning. R. J.: Hales, L. T.: Eriksen. R.: Nowak. B. Marme Freshwater Researh 2000,51. 1-10.

18. Vasconcelos. M. I. S. D.: Almeida. C. M. R.: Lage. O. M.: Sansonetty. F. Envirommental Toxicology and Chemistry 2000. 19 . $2542-2550$.

19. Kraft. K. J.; Sypniewski, R. H. Jomal of Great Lakes Research 1981. 7, 258-263

20. Marr. J. C. A.: Lipton. J.; Cacela, D; Hansen. J. A.; Meyer, J. S.; Bergman. H. L. Canadian Joumal of Fisheries and Aquatic Sciences 1999. $56.1471-1483$.

21. Misra. V: D. P. S.: Viswanathan. P. N. Chemisty and Ecolog' 1996. $13,103-112$.

22. Leddy: D. G.: Baglev, S. T.: Bornhorst, T. J.: Bowen, S. H.: Charland. W. W. Dorie, L. D.; Erbisch, F. H.: MeDowell. D. S.: Rose. W. I.: Spence. J. A. Torch Lake Studu A Project Completion Report): Michigan Department of Natural Resources: Houghton. 1986.

23. Narwall, R. P. Singh. B. R. Conmmin. Soil Sci. Plant Anal. 2001. $32.331-349$

24. Dumestre. A.: Sauve. S: McBride, M.: Baveve, P; Berthelin, J Arch Enwon. Contam. Toxicol 1999. 36. 124-131.

25. Tessier. A.: Campbell. P. G. C.: Bisson. M. Analytical Chemisty 1979. 51. 844-851.

26. Ubald. G;: Dahlgren. R. A. Soil Science 1994, 158, 409-420

27. Martin. J. M.: Nirel, P.: Thomas, A. J. Horine Chenism 1987.22. 313-341.

28. Guy. R. D.: Chakrabarti. C. L.: Mcbain. D. C. Water Research 1978. 12.21-24

29. McLaren. R. M.: Crawford. D. V. Joumal of Soil Science 1973. 24. 173-181

30. Shannon. R. D.: White J. R. Biogeochemistry 1991, 1t. 193-208.

31. Kennedy. A. D. Reconen of Copper front Hichigan Stamp Sands: Iol. II Phusical and Chemical Properties of Stamp Sands. Institute of Mineral Research. Michigan Technological University: Houghton1. 1970.

32. Heinrich, E. W. The Hineralogy of Michigan Speaker-Hines and Thomas, Ine: Lansing, Michigan, 1976.

33. Clarke, D. H. Copper Mines of Keweenaw; Albany and Boston Mining Company: Houghton. MI. 1986.

34. Sigg. L. In Chemical Processes in Lakes: Stumm. W. Ed.: Joht1 Wiley \& Sons: New York. 1985: pp 283-310.

35. Kuwabara, J. S; Leand. L. V; Bencala, K. F. J. En wiron. Eng. 1984. 110,646 .

36. Chapman. B. M. Water Resonces Research 1982.18, 155-167.

37. Walton-Day. K.: Filipek. L. H.: Papp. C. S. E. Geochemical. Cosmo. Acta 1990. 5t. 2933-2945. 